\title{
ORIENTATION TO FREEDOM AND POWER OF AMBITIOUS PERSON IN EARLY ADOLESCENCE
}

\author{
Oksana V. Barsukova \\ Chair of Psychology of Education, Faculty of Pedagogy and Practical Psychology, \\ Southern Federal University, Russia \\ knesinka@mail.ru
}

Original Scientific Paper doi:10.5937/jouproman8-24622

\begin{abstract}
The article presents the results of an empirical study of orientation to power and freedom of an ambitious person. Ambition, orientation to power and freedom are understood as motives of a person's social activity. People who consider themselves ambitious have a medium $(53.33 \%)$ and high $(46.66 \%)$ orientation to freedom, a low $(60 \%)$ and medium $(40 \%)$ orientation to power.
\end{abstract}

Key words: social activity, ambition, orientation to power, orientation to freedom, young people (early adolescence).

The issues of motivation of human social activity are both classical and relevant for modern psychology. Social activity is an important factor in human development. This is a combination of purposeful human activity and its sociopsychological qualities. A person defends their values, maintains or changes the social environment, the social circumstances of their life. Social activity of a person is polymotivated. In this case, we consider such motives of social activity as ambition, orientation to power and orientation to freedom:

- Ambition is a person's desire to become a significant and recognized person for other people for real achievements.
- Orientation to freedom is a person's desire to be able to choose, want, and act.

- Orientation to power is a person's desire to dominate,to control other people,to influence others.

The aim of empirical research is to take the orientation to freedom and power of young people who consider themselves ambitious.

The study involved 96 young people (age of 18 and 25).

The study was conducted using a questionnaire of self-esteem for ambition (O. Barsukova, 2016) and a test for the diagnosis of socio-psychological personality attitudes in the motivationalneed sphere (O. Potemkina, 2001).

The study of self-esteem of ambition showed that most young people (93.75\%) consider themselves ambitious. And only a minimal number of young people $(6.25 \%)$ do not consider themselves ambitious. Unfortunately, due to the small number of young people who do not consider themselves ambitious, a comparative analysis is not possible. 
The study of freedom orientation of ambitious people showed:

- A high orientation to freedom is characteristic for $46.66 \%$ of young people.

- An average orientation to freedom was found in $53.33 \%$ of young people.

- Low orientation to freedom is not revealed.

It should be noted that all young people $(100 \%)$ who do not consider themselves ambitious have an average orientation to freedom.

The study of the power orientation of ambitious people showed:

- An average orientation to power is found in $40 \%$ of young people.

- A low orientation to power was found in $60 \%$ of young people.

- High orientation to power is not revealed.

It is noteworthy that none of the young people indicated power as their ambitious goals.

The following fact is an unexpected result:

- prevalence of low orientation to power;

- lack of "power" as a goal

According to psychological sources

(for example, in psychoanalysis), an ambitious person seeks power, although not always. Nevertheless, the desire for power is one of the markers of ambition. So, the empirical study of orientation to powerof ambitious person should be continued.
To clarify, all young people, who do not consider themselves ambitious, have a low orientation to power.

The analysis of the combination of level of orientation to power and level of orientation to freedom showed:

- An average orientation to freedom and a low orientation to power is represented by $33.33 \%$ of young people.

- A high orientation to freedom and a low orientation to power is represented by $26.66 \%$ of young people.

- A high orientation to freedom and an average orientation to power is represented by $20 \%$ of young people.

- An average orientation to freedom and the average orientation to power is represented by $20 \%$ of young people.

Thus, the majority of young ambitious people are characterized by: an average orientation toward freedom; a low power orientation; a combination of average orientation to freedom and low orientation to power.

\section{Literature:}

1. Barsukova, O. V. [2016]. Psychological characteristics of ambitious person. Journal of Process Management. New Technologies , 4(2), 79-80.

2. Барсукова О. В. [2013]. Честолюбие: возможности эмпирического исследования и психологической диагностики // Известия Южного федерального университета. Педагогические науки. №1.Ростов-Н/Д., 2013.C. 107-112. 
3. Ильин Е.П. [2014]. Психология зависти, враждебности, тщеславия. - СПб.: Питер, 208.

4. O.F.Potemkinoy. [2001]. Metodika diagnostiki sotsial'no-psikhologicheskikh ustanovok lichnosti v motivatsionnopotrebnostnoy sfere / Prakticheskaya psikhodiagnostika. Metodiki i testy. Uchebnoye posobiye. Red. i sost. Raygorodskiy D.YA. - Samara, S.641648. 